As public libraries are becoming e-government access points relied on by both patrons and government agencies, it is important for libraries to consider the implications of these roles. While providing e-government access serves to reinforce the tremendously important role of public libraries in the United States social infrastructure, it also creates new demands on libraries and opens up significant new opportunities. Drawing upon several different strands of research, this paper examines the nexus of public libraries, values, trust, and e-government, focusing on the ways in which the values of librarianship and the trust that communities place in their public libraries reinforce the role of public libraries in the provision of e-government. The unique values embraced by public libraries have not only shaped the missions of libraries, they have influenced popular opinion surrounding public libraries and fostered the confidence that communities place in them as a source of trusted information and assistance in finding information. As public libraries have embraced the provision of Internet access, these values and trust have become intertwined with their new social role as a public access point for e-government both in normal information activities and in the most extreme circumstances. This paper explores the intersections of these issues and the relation of the vital e-government role of public libraries to library funding, public policy, library and information science education, and research initiatives.

$\mathbf{P}$ ublic libraries have always been valued and trusted institutions within society. Due to recent advances in technology and changes in United States society, public libraries now also play a unique and critical role by offering free public Internet access. With the increasing reliance on the Internet as a key source of news, social capital, and access to government services and information, the free access provided by public libraries is an invaluable resource. As a result, a significant proportion of the U.S. population, including people

Paul T. Jaeger (pjaeger@umd.edu) is an Assistant Professor and Director of the Center for Information Policy and Electronic Government at the College of Information Studies of the University of Maryland, College Park. Kenneth R. Fleischmann (kfleisch@umd.edu) is an Assistant Professor at the College of Information Studies of the University of Maryland, College Park. who have no other means of access, people who need help using computers and the Internet, and people who have lower quality access, rely on the Internet access and computer help available in public libraries. Federal, state, and local government agencies now also rely on public libraries to provide citizens with access to and guidance in using e-government Web sites, forms, and services; many government agencies simply direct citizens to the nearest public library for help. This confluence of events has created a major new social role for public librariesguarantors of Internet and e-government access.

Though public libraries are not the only points of free Internet access in many communities, they have created the strongest commitment to providing access and help for all. By providing not only the access to technology, but also to help using the technology, libraries became Internet access points, while community technology centers, which usually did not offer the same level of available assistance, failed in the late 1990s and early 2000s. Further, as libraries not only provide Internet access, but free computer access as well, they attract the people who do not own computers and do not benefit from a city's or coffee shop's free Wi-Fi. The compelling combination of free computer access, free Internet access, the availability of assistance from knowledgeable librarians, the value that public librarians place on serving their local communities, and the historical trust that society places in public libraries has made libraries a critical part of the U.S. social infrastructure. Without public libraries, large segments of the population would be cut off from access to the Internet and e-government.

While the provision of Internet access for those who have no other access parallels the role of public libraries as providers of access to print materials, the maturation of public libraries into Internet and e-government access hubs has profound implications for the roles that public libraries are being expected to play in their communities. Public libraries are trusted by their communities as places that community members can turn to for unfettered information access and as places to go for information in times of need. Combining this trust with the power of Internet access and support makes public libraries even more critical within their local communities. The trust placed in libraries is also important in balancing the lack of confidence that many citizens place in other government institutions as well as in the Internet. Clearly, e-government, which exists at this intersection, has its trustworthiness bolstered by the role of public libraries in its use. As patrons are able to access e-government through the library-a place that is trusted-they may have greater confidence in the government services they use through library computers and with the assistance of librarians.

The important role of libraries in providing citizens with access to the Internet, and especially to e-govern- 
ment, makes natural sense given the values of the public library. These new services reflect the values traditionally upheld by public libraries, such as equal access to information, literacy and learning, and democracy. Indeed, these values likely have played a significant role in developing and sustaining public trust in public libraries as institutions. Thus, to understand how public libraries have come to serve as the default site for e-government access, it is important to consider how this role builds on and reflects the public library's enduring values.

Drawing upon several different strands of research, this article explores the intersections of public libraries, values, trust, and e-government. The article first examines the values of public libraries and the role that these values play in influencing popular opinion surrounding public libraries. Next, the article focuses on the trust that communities place in public libraries, which builds upon the values that libraries uphold. After that, the article explores the reasons why public libraries became and remain the public access point for e-government, providing examples from the 2004 and 2005 hurricane seasons that illustrate this point in the most extreme circumstances. The article then examines the nexus of public libraries, values, trust, and e-government, further examining how the values of librarianship and the confidence that communities place in their public libraries reinforce the role of public libraries in the provision of e-government. Finally, the article explores how the e-government role of public libraries could be cultivated to improve library services through involvement in research and educational initiatives.

\section{Public libraries and values}

Values can be seen as "evaluative beliefs that synthesize affective and cognitive elements to orient people to the world in which they live." ${ }^{11}$ In other words, values tie together how individuals think about the world and how they feel about the world. Following this definition, values are situated within individuals. Although they are a result of social interaction and may be shared among individuals, values are a highly individualized and personalized phenomenon. Thus, values arise at the intersection of the individual and the social, with some scholars now making a case for increasing the emphasis placed on values in the social sciences. ${ }^{2}$ Recently, many scholars and commentators have focused on the values of libraries, most notably former ALA president Michael Gorman, who has written extensively on the topic. ${ }^{3}$

Gorman focuses on library values in response to what he views as a disconnect between library practitioners and academics. He argues that library-science programs are becoming increasingly detached from reality, and that one way to ground library science, as well as the library profession, is through an emphasis on the values of librarianship, which demonstrate the core, enduring values of the profession. ${ }^{4} \mathrm{He}$ explains that values, on the one hand, should provide a foundation for interaction and mutual understanding among members of a profession; on the other hand, they should not be viewed as immutable, but rather as sufficiently flexible to match the changing times. He lists eight central values of librarianship that he views as particularly salient at present: stewardship, service, intellectual freedom, rationalism, literacy and learning, equity of access to recorded knowledge and information, privacy, and democracy.

Frances Groen echoes Gorman's sentiments and argues that one of the major limitations of library-science programs is their lack of attention to values. ${ }^{5}$ She argues that library and information science (LIS) programs place almost all of their educational emphasis on what librarians do and how they do it, and almost none on the reasons why they do what they do and why such activities are important. She identifies three fundamental library values: access to information, universal literacy, and preservation of cultural heritage, all of which she argues are also characteristics of liberal democratic societies. This argument parallels the observation that increases in information access within a society are essential to increasing the inclusiveness of the democratic process in that society. ${ }^{6}$

Library historian Toni Samek focuses on another aspect of library values that is no longer as strongly emphasized-attempts to achieve neutrality in libraries. ${ }^{7}$ Neutrality often was advocated as a cherished value, in the sense of providing equal access to all information and sources. However, Samek demonstrates that libraries, on the contrary, were more likely to emphasize mainstream information sources and thus privilege them over alternative sources. Not only has the value of neutrality been problematic in terms of how it has been implemented and mobilized in public libraries in the 1960s and 1970s, but it also is perhaps impossible to ever achieve in reality. ${ }^{8}$ The fact that neither Gorman nor Groen include neutrality in their listings of fundamental library values demonstrates how library values have continued to evolve as public libraries have developed as social institutions.

As library values have developed, they have served to unite librarians and establish the role of public libraries in their communities. The values of librarianship have been encoded in the American Library Association's (ALA) Library Bill of Rights, which strongly asserts the values of equal access and service for all patrons, nondiscrimination, diversity of viewpoint, and resistance to censorship and other abridgments of freedom of expression. ${ }^{9}$ The values of libraries and librarianship are one of the factors that lead communities to trust public libraries, as the following section explores. Overall, further study of the 
role of values in libraries is essential, especially given the increasing role of technology in public libraries. ${ }^{10}$

\section{Public libraries and trust}

Exactly one half of the respondents to a 2007 Pew Research Center study agreed with the statement "You can't be too careful in dealing with people."11 However, even in a climate where trust can be a precious commodity, public libraries are trusted by their communities. Carr argues that libraries have come to earn the trust of their communities because of four obligations that librarians strive to meet: to provide user-centered service, to actively engage in helping users, to connect information seekers to unexplored information sources, and to take the goal of helping users as a professional duty that is controlled first and foremost by the library user. ${ }^{12}$ Similarly, Jaeger and Burnett argue that, because of its traditional defense of commonly accepted and popular values-such as free access to and exchange of information, providing a diverse range of materials and perspectives to users from across society, and opposition to government intrusions into personal reading habits-public libraries have come to be seen by members of the populace as a trusted source of information in the community. ${ }^{13}$

Gorman argues for a direct link between the values of libraries and the trust that is instilled within them by the public, stating that one important mission for ensuring the survival of libraries and librarianship is "assuring the bond of trust between the library and the society we serve by demonstrating our stewardship and commitment, thus strengthening the mutuality of the interests of librarians and the broader community."14 Further, a 2006 study conducted by Public Agenda found that "public libraries seem almost immune to the distrust that is associated with so many other institutions." 15

In specific terms of the Internet, the public library "is a trusted community-based entity to which individuals turn for help in their online activities - even if they have computers and Internet access at home or elsewhere."16 In a largescale national survey, 64 percent of respondents, including both users and non-users of public libraries, asserted that providing public access to the Internet should be one of the highest priorities for public libraries. ${ }^{17}$ Thus, trust in public libraries seems to carry over from other library services to provision of Internet access and training.

However, challenges to trust in public libraries seem to be growing in the Internet age. The trusted role of protecting users' personal information may create conflicts with the other social responsibilities of public libraries. ${ }^{18}$ As a result of a lack of preparedness of some librarians to deal with privacy issues, it is possible that "the trust that research shows users place in libraries is not fully repaid."19 A 2005 OCLC study suggests that, indeed, user trust in public libraries shows signs of weakening, as the majority of citizens place as much trust in Internet search engines as they do in public libraries. ${ }^{20}$ Further, the changes in the law following the $9 / 11$ terror attacks that have increased the ability of the federal government to track patron activities in public libraries, such as through the USA PATRIOT Act, have raised serious concerns about privacy and freedom of expression among many public library patrons and librarians. ${ }^{21}$

Trust in libraries also has been challenged by the imposition of filters for public libraries that receive E-rate funding due to the Children's Internet Protection Act. ${ }^{22}$ While Internet access is no longer unfettered in libraries that have to comply with the law, public libraries have been able to prevent this law from eroding their role as trusted Internet provider through ALA's vigorous legal challenge to the constitutionality of law and the rejection of E-rate funds by a large number of libraries after the Supreme Court upheld the constitutionality of the law. ${ }^{23}$ Thus, the trusting relationships that public libraries have built with their communities are valuable commodities that can be transferred under some circumstances from one particular service to another, yet are not inalienable rights granted to public libraries. Rather, public trust is something that libraries must work hard to maintain. Trust in public libraries also has served as an important cause and effect of the role of libraries in providing access to e-government.

\section{Public libraries and e-government}

Public libraries are not only trusted as a means of access to the Internet in general, they are trusted as a provider of access to e-government. With nearly every United States public library now connected to the Internet and offering free public access, they can fill a community need of ensuring that all citizens have access to e-government and assistance using e-government services. ${ }^{24}$ Indeed, public libraries and the Internet have both improved public access to government information. ${ }^{25}$

This social role also is embraced by all levels of government, with government agencies often directing people with questions about their online materials to public libraries for help. ${ }^{26}$ As such, government agencies also trust public libraries to serve as key providers of egovernment access and training. Public libraries could not have foreseen becoming the default social access point for e-government when they began to provide free public Internet access in the mid-1990s, due in great part to the largely separate evolution of Internet access in libraries and e-government. However, they now fill this role in society, ensuring access to those who have no other means of reaching e-government and providing a safety 
net of training and assistance for those who have access but need help using e-government.

Public libraries have developed into the social source of e-government for two reasons. The first is simply that libraries committed to the provision of public Internet access in the early 1990s and have continued to grow and improve that access so that virtually all public libraries in the United States provide free public Internet access. ${ }^{27}$ However, presence of access alone does not account for the current role of the public library, as most public schools and government offices have Internet access, and community technology centers were originally funded to create an environment that would provide computer access. A key difference in public libraries is that they are historically trusted as providers of information, including government information, to all segments of society. "The public library is one place that is culturally ingrained as a trusted source of free and open information access and exchange." 28

A key part of the provision of Internet access in public libraries also has been providing help. As Heanue explains, "even if Americans had all the hardware they needed to access every bit of government information they required, many would still need the help of skilled librarians whose job it is to be familiar with multiple systems of access to government systems." ${ }^{29}$ Not only is the information trusted because of the source, the help is trusted because the librarians are part of the library. As e-government has developed and the complexity has grown, this trusted help has become invaluable to many people who need to use e-government but do not feel able to on their own. In a 2001 study of both public library and Internet users, the key preferences identified for public libraries included the ease of use, accuracy of information available, and help provided by library staff. ${ }^{30}$ These perceptions have carried over into e-government, as the staff members not only provide help using e-government; their guidance directs users to the correct e-government sites and forms and makes using the sites an easier experience than it otherwise would be.

In the era of e-government, governments internationally are showing a strong preference for delivering services via the Internet, particularly as a means of boosting cost-efficiency and reducing time spent on direct interactions with citizens. ${ }^{31}$ However, citizens show a strong preference for phone-based or in-person interactions with government representatives when they have questions or are seeking services. ${ }^{32}$ E-government services generally are limited by difficulties in searching for and locating the desired information, as well as lack of availability of computers and Internet access to many segments of the general population. ${ }^{33}$ Such problems are exacerbated by general lack of familiarity of the structure of government and which agencies to contact as well as many citizens' attitudes toward technology and government. ${ }^{34}$ Also, as e-government sites give more emphasis to presenting political agendas rather than promoting democratic participation, users are less trusting of the sites themselves..$^{35}$ Finally, perhaps the most compelling reason for the reliance on public libraries to provide access to and help with e-government is that public libraries provide support equally to all members of a community-and that free services are of most relative value to those who have the fewest resources of their own.

As a result of the reliance of patrons and government agencies on the public library as a center for e-government access and assistance, public librarians have had to become de facto experts on e-government, ranging from Medicare prescription plans to FEMA forms to immigration registration to water management registration. ${ }^{36}$ In one case, the involvement of a librarian who specialized in government information was necessary in a community planning process to sort through the related e-government materials and information sources. ${ }^{37}$ One area where the social roles as provider of e-government and as trusted provider of information were notably intertwined was during the 2004 and 2005 hurricane seasons along the Gulf Coast.

\section{Public libraries as trusted provider of e-government}

Public libraries have become vital access points and communication hubs for many communities and, in times of emergency, are vital in helping their communities cope with the crisis. ${ }^{38}$ This role proved especially important in communities along the Gulf Coast during the unprecedented 2004 and 2005 hurricane seasons, with public libraries employing their Internet access to assist their communities in hurricane recovery in numerous ways. The public libraries in that region described five major roles for the public library Internet access in communities after a hurricane:

- finding and communicating with dispersed and displaced family members and friends;

- completing FEMA forms, which are online only, and insurance claims;

- searching for news about conditions in the areas from which they had evacuated;

- trying to find information about the condition of their homes or places of work, including checking news sites and satellite maps; and

- helping emergency service providers find information and connect to the Internet. ${ }^{39}$

The provision of e-government information and assistance in filling out e-government forms was a central function of these libraries in helping their communities. The level of assistance was astounding-one Mississippi library completed more than forty-five thousand FEMA 
applications for patrons in the first month after Katrina struck-despite the fact that the libraries were not specifically prepared to offer such a service and that few library systems planned for this type of situation. ${ }^{40}$ Furthermore, while libraries helped many communities, they could not meet the enormous needs in the affected communities. The events along the Gulf Coast in 2004 and 2005 revealed a serious need for the integration of local and state public entities that have large-scale coordination plans to work with the libraries. ${ }^{41}$

Most of the functions that community organizations played in the most ravaged areas after Katrina, Rita, Wilma, Dennis, Ivan, and the other major storms were completely ad hoc and unplanned. ${ }^{42}$ The federal government was of little help in the immediate aftermath of many of these situations. ${ }^{43}$ As such, it was the local community organizations, particularly public libraries, that used information technology (at least what was still working) to try to pick up the pieces, get aid, find the missing, and perform other vital functions. Consider the following quotes from local government officials explaining the role computers and Internet access in public libraries played in providing information to devastated communities:

Our public access computers have been the only source of communicating with insurance carriers, the Federal Emergency Management Agency and other sources of aid.

The greatest impact has been access to information such as FEMA forms and job applications that are ONLY available via Internet. This was highly visible during the aftermath of hurricanes Rita \& Katrina. Overall access to information in this rural community has been outstanding due to use of the Internet.

Relief workers were encouraged to use the library to keep in touch with family and friends through email. . . The Library provided a FEMA team with local maps and help in locating areas that potentially suffered major damage from the storm.

During the immediate aftermath of Katrina, our computers were invaluable in locating missing family, applying for FEMA relief (which could only be done online) and other emergency needs. For that time-the computers were a Godsend.

We have a large number of displaced people who are coming to rely upon the library in ways many of them never expected. I've had so many people tell me that they had never been to a library before they had to find someplace to file a FEMA application or insurance claim. Many of these people knew nothing about computers and would have been totally lost without the staff's help. ${ }^{44}$
Along with e-government access, one of the greatest affects of access to information related to searches for lost family, friends, and pets, with many libraries creating lists of individuals who had been to the library and who were being sought to help in establishing contacts between people. As one librarian stated, "our computers were invaluable in locating a missing family." 45 Searches were conducted by patrons and by librarians helping them to locate evacuees and search for information about those who stayed behind. Internet access also allowed patrons to have "contact with family members outside of the disaster area," "communicate with family and friends," and "stay in touch with family and friends due to lack of telephone service." 46 Libraries used their Internet access to aid rescue personnel to communicate with their agencies, and even to direct emergency responders with directions, maps, and information about where people most needed help. ${ }^{47}$

The level of local libraries' success in meeting the needs of their communities after the hurricanes varied widely, though. Many were simply overwhelmed by the numbers of people in need and limited by the fact that they had never expected to have to act as a community lifeline in this way. ${ }^{48}$ The libraries that faired the best were usually in Florida; they have a greater familiarity with dealing with hurricanes and thus were more prepared and had more established ties between local libraries, county governments, and state agencies. ${ }^{49}$ Having Internet access and expertise is clearly not enough. Planning, coordination, experience, and government support and funding all influenced how different public libraries were able to respond after the major hurricanes. Public libraries also may be able to play a role in ongoing emergency response efforts, such as the development of large-scale community response grids that coordinate citizens and emergency responders in emergencies. ${ }^{50}$

The greatest lesson, however, may be that public libraries, as trusted providers of information technology access, particularly access to e-government, are the most local line of response in communities. The national government failed shatteringly and completely to help people after Hurricane Katrina, while little public libraries in and on the edges of the devastation hummed along. The local nature of the response that libraries could provide managed to reach communities and members of those communities much better than national or state level responses. Such local response to crises, while vital, is becoming much harder to find outside of public libraries.

\section{The nexus of public libraries, values, trust, and e-government}

The democratically oriented core values of public libraries and the trust that communities place in their public 
libraries have the potential to significantly enhance and strengthen the role of public libraries in the provision of e-government. Citizens who access e-government using computers in public libraries, and with the expert assistance of librarians, may have more confidence in the e-government information and services they are using as a result of their high regard for public libraries. As patrons trust that librarians will help them reach the information they need, patrons' awareness of and confidence in e-government will increase as they learn from librarians about the types of information and services available from e-government. Further, by teaching patrons what is available from and how to use e-government, librarians are serving to increase the number of e-government users. Because e-government is still at an early stage in its development, such positive associations could play a critical role in encouraging and facilitating its widespread acceptance and adoption.

Just as e-government is still in its formative stages, research on e-government also is just getting started. To date, research on e-government has focused more on technical than social aspects. For example, a metaanalysis of 110 peer-reviewed journal articles related to e-government revealed that the relationship between e-government and values is an important, yet to date understudied, topic. ${ }^{51}$ It is important to consider not only bandwidth and markup languages, but also values and trust in developing and analyzing e-government.

It also is important to consider the relationship between trust in e-government and the potential for increasingly participatory democracy. Trust can be seen as "centrally positioned at the nexus between the primarily internally driven administrative reforms of e-government's architecture and the related, more externally rooted pressures for e-governance reflected in widening debates on openness and engagement."52 Similarly, "citizen engagement can help build and strengthen the trust relationship between governments and citizens." 53 Through e-government, it is possible to facilitate citizen participation in government through the bidirectional interactive potential of the Internet, making it possible to move toward strong democracy. ${ }^{54}$ Greater faith in democracy can potentially significantly increase citizen trust in e-government.

At the same time that we consider all of these important issues related to e-government, it is important not to lose sight of the critical role that public libraries play in the provision of e-government. Further, it is necessary to make certain that public libraries receive credit and support for the work that they do in providing access to and help with e-government. As demonstrated above, public libraries are uniquely and ideally situated to ensure access to and assistance in using e-government information and services. However, this activity is not sustainable without the recognition and resources that must accompany this role. The conclusion addresses this important point in more detail.

\section{Conclusions and future directions}

The evolution of the public library into an e-government access point has occurred without the direct intention of public libraries and without their involvement in policy decisions related to these new social roles. As with the need to become more active in encouraging the development of technologies to help libraries fulfill these social expectations, public libraries also must become more involved in the policy-making process and in seeking financial and other support for these activities. Public libraries have to demand a voice not only to better convey their critical role in the provision e-government, but to help shape the direction of the policy-making process to ensure more government support for the access to and help with e-government that they provide.

Public libraries have taken on these responsibilities without receiving additional funding. While the provision of Internet access alone is a major expense for public libraries, the reliance of government agencies on public libraries as the public support system for e-government adds very significant extra burdens to libraries. ${ }^{55}$ In a 2007 survey of Florida public libraries, for example, 98.7 percent indicated that they receive no support from an outside agency to support the e-government services the library provides, despite the fact that 83.3 percent of responding libraries indicated that the use of e-government in the library had increased overall library usage. ${ }^{56}$ This lack of outside support has resulted in public libraries in different parts of the country having widely varying access to the Internet. ${ }^{57}$

The reality is that public libraries are expected by patrons and government agencies to fulfill this social role, whether or not any support-financial, staffing, or training-is provided for this role. The vital roles that public libraries played in the aftermath of the major hurricanes of the 2004 and 2005 seasons may have permanently cemented the public and government perception of public libraries as hubs for e-government access. ${ }^{58}$

While public libraries have become the unofficial universal access point for e-government and are trusted to serve as a vital community response and recovery agency during emergencies, they do not receive funding or other forms of external assistance for these functions. Public libraries need to become involved in and encourage plans and programs that will serve to sustain these essential and inextricably linked activities, while also bringing some level of financial, training, and staffing support for these roles.

The tremendous efforts and successes of public libraries in the aftermath of the 2004 and 2005 hurricanes has 
earned libraries a central position to e-government and emergency planning at local, state, and federal levels. In those emergency situations, public libraries were able to serve their communities in a capacity that was far beyond the traditional image of the role of libraries, but these emergency response roles are as significant as anything else libraries could do for their communities. In order to continue fulfilling these roles and adequately performing other expected functions, public libraries need to push not only for financial support, but also for a greater role in planning and decision-making related to e-government services as well as emergency response and recovery at all levels of government.

If strategic plans and library activities have a consistent message about the need for support, the interrelated roles of trusted source of local information, e-government access provider, and community-response information and coordination center can make a compelling argument for increases in funding, support, and social standing of public libraries. The most obvious source of further support for these activities would be the federal government. Amazingly, federal government support accounts for only about 1 percent of public library funding. ${ }^{59}$ Given that federal government agencies are already relying on public libraries to ensure access to e-government and foster community response and recovery in times of emergencies, federal support for these social roles of the public library clearly can and should be increased significantly.

State libraries, cooperatives, and library networks already work to coordinate funding and activities related to certain programs, such as the E-rate program. ${ }^{60}$ These same library collectives may be able to work together to promote the need for additional resources and coordinate those resources once they are attained. Private and public partnerships offer another potential means of support for these library activities. With its strong historical and current connections to technology and libraries, the Bill and Melinda Gates Foundation might be a very important partner in funding and facilitating the increased role that public libraries play in providing access to and help with e-government. The search for additional funding to support e-government provision should not only focus on funds for access and training, but also on funds for research about how to better meet individual and community e-government needs and the affects of e-government provision by public libraries on individuals and communities.

Regardless of what approaches are taken to finding greater support, however, public libraries must do a better job of communicating their involvement in the provision of e-government to governments and private organizations in order to increase support. Such communications will need to be part of a larger strategy to define a place within public policy that gives public libraries a voice in e-government issues. If public libraries are going to fulfill this social role, they must become a greater presence in the national policy discourse surrounding e-government. To increase their support and standing in policy discourse, libraries must not be hesitant in reminding the public and government officials of their successes after emergencies and in providing the social infrastructure for e-filing of taxes, enrolling in Medicare prescription drug plans, and myriad other routine e-government activities.

In many societies, e-government has come to be seen by many citizens and governments as a force that will enhance democratic participation, more closely link citizens and their representatives, and help disadvantaged populations become more active participants in government and in society. ${ }^{61}$ E-government is seen by many as having "the potential to fundamentally change a whole array of public interactions with government."62 While the E-government Act of 2002 and President's E-government Management Agenda have emphasized the transformative effect of e-government, thus far it has primarily been used as a way to make information available, provide forms and electronic filing, and distribute the viewpoints of government agencies. ${ }^{60}$ However, many citizens do look to e-government as a valuable source of information, considering e-government sites to be "objective authoritative sources." 64 Currently, the primary reason that people use e-government is to gather information. ${ }^{65}$ In the United States, 58 percent of Internet users in the United States believe e-government to be the best source for government information, 65 percent of Americans expect that information they are seeking will be on a government site, and 26 million Americans seek political information online everyday. ${ }^{66}$

Public satisfaction with the e-government services available, however, is limited. As commercial sites are developing faster and provide more innovative services than e-government sites, public satisfaction with government Web sites is declining. ${ }^{67}$ Public confidence in government Web sites also has declined as much of the public policy related to e-government since 9/11 has been to reduce access to information through e-government. ${ }^{68}$ The types of information that have been affected include many forms of socially useful information, from scientific information to public safety information to information about government activities. ${ }^{69}$ For these and other reasons, the majority of citizens, even those with a high-speed Internet connection at home, seeking government information and services prefer to speak to a person directly in their contacts with the government. ${ }^{70}$ In many cases, people turn to public librarians to serve as the person involved in e-government contacts.

Further, when people struggle with, become frustrated by, or reject e-government services, they turn to public libraries. Every year, public libraries deal with huge numbers of patrons needing help with online taxes, and the Medicare prescription drug plan sign-up period resulted in 
an influx of seniors to public libraries seeking help in using the online registration system. ${ }^{71}$ For example, during the 2006 tax season, Virginia discontinued the distribution of free print copies of tax forms to encourage use of the online system. Instead, citizens of the state flooded public libraries, assuming that libraries could find them print copies of the forms, which of course the libraries did.

It seems unlikely, however, that the same government officials pushing the use of e-government are aware of the roles of public libraries in helping citizens with day-to-day e-government use. Further, the enormous social roles of public libraries in emergency response in communities, such as during the 2004 and 2005 hurricane seasons, are far from widely known among government officials. To encourage the provision of external funding, the development of targeted support technologies, and policy support for these social roles, public libraries must make the government and the public better aware of these roles and what is needed to ensure that the roles can be fulfilled.

Similarly, there is an extremely important role for LIS programs in ensuring public libraries can meet community expectations for e-government provision. LIS program graduates need to be prepared to help patrons access and use e-government information and services. As government activities move primarily or exclusively online, patrons will increasingly seek help with e-government from public libraries. LIS programs must ensure that graduates are ready to serve patrons in this capacity. In 2007, the College of Information Studies at the University of Maryland became the first ALA-accredited school to offer a concentration in e-government as part of the Master of Library Science program. ${ }^{72}$ The goal of this concentration is to prepare future librarians who wish to specialize in e-government, which will be an area of increasing and significant need as more government information and services move online and more government agencies rely on public libraries to ensure access to e-government. LIS programs need to prioritize finding ways to incorporate the teaching of issues related to e-government in public libraries as new concentrations or courses, or into existing courses. The provision of e-government is an important role of public libraries that is likely to increase significantly, and graduates of LIS programs need to be prepared to meet patrons' e-government information needs. Further, LIS faculties also can support public libraries in their e-government access and training roles by focusing more research on the intersections of public libraries and e-government.

Ultimately, the role of the trusted and valued public provider of e-government access creates many financial and staffing obligations and social responsibilities, but it also is a tremendous opportunity for public libraries. Fighting against censorship efforts in the 1950s established the public perception of libraries as guardians of the First Amendment during the McCarthy era. ${ }^{73}$ Working to ensure access and the ability to use e-government is creating new public perceptions of libraries as guardians of equal access in new but just as socially meaningful ways. Rather than needing to ponder whether the emergence of the Internet will limit or remove the relevance of public libraries, the advent of e-government has created a brand new and very significant role that public libraries can play in serving their communities. Given the emphasis that governments are placing on moving information and services online, patrons will continue to need access to and assistance in using e-government.

The trust and values that have long been associated with public libraries are evolving to include the social expectations of the provision of access to and training for e-government by public libraries. In the same ways that patrons have learned to trust public libraries to provide equal access to print information sources, they now have learned to trust that libraries can provide equal access to e-government information. It seems that citizens will regularly be turning to public libraries for help with mundane e-government activities, such as finding forms and filing taxes, as well as with the most pressing e-government activities, as was demonstrated in the aftermath of hurricanes Katrina and Rita. Because the trust in and values of public libraries have set the stage for the emerging role of libraries in e-government, public libraries need to work to ensure the availability of the support, education, and policy decisions that they need to serve their communities in this new and vital role in situations ranging from everyday information needs to the most extreme circumstances.

In spite of the costs associated with serving as the public's e-government access center, acting as the social guarantor of equal access to e-government emphatically demonstrates that public libraries will continue to be a central part of the infrastructure of society in the Internet age. Public libraries now must learn to articulate better the social roles they are playing and the types of support they need from LIS programs, funding agencies, and government agencies to continue playing these roles.

\section{Acknowledgment}

The authors of this paper have worked with several colleagues on projects related to the ideas discussed in this paper. The authors would particularly like to thank John Carlo Bertot, Lesley A. Langa, Charles R. McClure, Jennifer Preece, Yan Qu, Ben Shneiderman, and Philip Fei Wu.

\section{References and notes}

1. Margaret Mooney Marini, "Social Values and Norms," Encyclopedia of Sociology, Edgar F. Borgatta and Marie L. Borgatta, eds., 2828 (New York: Macmillan, 2000). 
2. Steven Hitlin and Jane Allyn Piliavin, "Values: Reviving a Dormant Concept," Annual Review of Sociology 30 (2004): 359-93.

3. Michael Gorman, Our Singular Strengths: Meditations for Librarians (Chicago: ALA, 1997); Michael Gorman, Our Enduring Values: Librarianship in the 21st Century (Chicago: ALA, 2000); Michael Gorman, Our Own Selves: More Meditations for Librarians (Chicago: ALA, 2005).

4. Gorman, Our Enduring Values.

5. Frances K. Groen, Access to Medical Knowledge: Libraries, Digitization, and the Public Good (Lanham, Md.: Scarecrow, 2007).

6. Elizabeth Smith, "Equal Information Access and the Evolution of American Democracy," Journal of Educational Media and Library Sciences 33, no. 2 (1995): 158-71.

7. Toni Samek, Intellectual Freedom and Social Responsibility in American Librarianship, 1967-1974 (Jefferson, N.C.: McFarland, 2001).

8. Pam Scott, Evelleen Richards, and Brian Martin, "Captives of Controversy: The Myth of the Neutral Social Researcher in Contemporary Scientific Controversies," Science, Technology, and Human Values 15 (1990): 474-94.

9. American Library Association, "Library Bill of Rights," www.ala.org/ala/oif/statementspols/statementsif/librarybillrights.htm (accessed May 19, 2007).

10. Kenneth R. Fleischmann, "Digital Libraries with Embedded Values: Combining Insights from LIS and Science and Technology Studies," Library Quarterly (in press); Kenneth R. Fleischmann, "Digital Libraries and Human Values: HumanComputer Interaction meets Social Informatics," Proceedings of the 70th Annual Conference of the American Society for Information Science and Technology, Milwaukee, Wisc., 2007.

11. Pew Research Center, Americans and Social Trust: Who, Where, and Why (Washington, D.C.: Pew Research Center, 2007), http://pewresearch.org/assets/social/pdf/SocialTrust.pdf, 2.

12. David Wildon Carr, "An Ethos of Trust in Information Service," in Ethics and Electronic Information: A Festschrift for Stephen Almagno, Barbara Rockenbach and Tom Mendina, eds., 45-52 (Jefferson, N.C.: McFarland, 2003).

13. Paul T. Jaeger and Gary Burnett, "Information Access and Exchange among Small Worlds in a Democratic Society: The Role of Policy in Redefining Information Behavior in the Post9/11 United States," Library Quarterly 75, no. 4 (2005): 464-95.

14. Gorman, Our Enduring Values, 66.

15. Public Agenda, Long Overdue: A Fresh Look at Public and Leadership Attitudes about Libraries in the 21st Century (New York: Public Agenda, 2006), 11, www.publicagenda.org/research/ pdfs/long_overdue.pdf (accessed May 19, 2007).

16. John Carlo Bertot et al., "Public Access Computing and Internet Access in Public Libraries: The Role of Public Libraries in E-government and Emergency Situations," First Monday 11, no. 9 (2006), www.firstmonday.org/issues/issue11_9/bertot (accessed May 19, 2007).

17. Public Agenda, Long Overdue.

18. Nancy Zimmerman and Feili Tu, "It Is Not Just a Matter of Ethics II: An Examination of Issues Related to the Ethical Provision of Consumer Health Services in Public Libraries," Ethics and Electronic Information: A Festschrift for Stephen Almagno, Barbara Rockenbach and Tom Mendina, eds., 119-27 (Jefferson, N.C.: McFarland, 2003).
19. Paul Sturges and Ursula Iliffe, "Preserving a Secret Garden for the Mind: The Ethics of User Privacy in the Digital Library," Ethics and Electronic Information: A Festschrift for Stephen Almagno, Barbara Rockenbach and Tom Mendina, eds., 74-81 (Jefferson, N.C.: McFarland, 2003), 81.

20. Online Computer Library Center, Inc. (OCLC), Perceptions of Libraries and Information Resources: A Report to the OCLC Membership (Dublin, Ohio: OCLC, 2005).

21. Jaeger and Burnett, "Information Access and Exchange among Small Worlds in a Democratic Society"; Paul T. Jaeger et al., "The USA PATRIOT Act, the Foreign Intelligence Surveillance Act, and Information Policy Research in Libraries: Issues, Impacts, and Questions for Library Researchers," Library Quarterly 74, no. 2 (2004): 99-121.

22. Children's Internet Protection Act, Public Law 106-554.

23. Paul T. Jaeger, John Carlo Bertot, and Charles R. McClure, "The Effects of the Children's Internet Protection Act (CIPA) in Public Libraries and its Implications for Research: A Statistical, Policy, and Legal Analysis," Journal of the American Society for Information Science and Technology 55, no. 13 (2004): 1131-39; Paul T. Jaeger et al., "CIPA: Decisions, Implementation, and Impacts," Public Libraries 44, no. 2 (2005): 105-09.

24. Bertot et al., "Public Access Computing and Internet Access in Public Libraries"; John Carlo Bertot et al., "Drafted: I Want You to Deliver E-government," Library Journal 131, no. 13 (2006): 34-39; John Carlo Bertot et al., Public Libraries and the Internet 2006: Study Results and Findings (Tallahassee, Fla.: Information Institute, 2006), www.ii.fsu.edu/plinternet_reports.cfm (accessed May 19, 2007).

25. Nancy Kranich, "Libraries, the Internet, and Democracy," Libraries \& Democracy: The Cornerstones of Liberty, Nancy Kranich, ed., 83-95 (Chicago: ALA, 2001).

26. Bertot et al., "Public Access Computing and Internet Access in Public Libraries"; Bertot et al., "Drafted."

27. Bertot et al., Public Libraries and the Internet 2006.

28. Jaeger and Burnett, "Information Access and Exchange among Small Worlds in a Democratic Society," 487.

29. Anne Heanue, "In Support of Democracy: The Library Role in Public Access to Government," Information, Libraries, and Democracy: The Cornerstones of Liberty, Nancy Kranich, ed. (Chicago: ALA, 2001), 124.

30. George D'Elia et al., "The Impact of the Internet on Public Library Uses: An Analysis of the Current Consumer Market for Library and Internet Services," Journal of the American Society for Information Science and Technology 53, no. 10 (2002): 802-20; Eleanor Jo Rodger, George D'Elia, and Corrine Jorgensen, “The Public Library and the Internet: Is Peaceful Coexistence Possible?," American Libraries 31, no. 5 (2001): 58-61.

31. W. E. Ebbers, W. J. Pieterson, and H. N. Noordman, “Electronic Government: Rethinking Channel Management Strategies," Government Information Quarterly (in press).

32. Ibid.

33. Awdhesh K. Singh and Rajendra Sahu, "Integrating Internet, Telephones, and Call Centers for delivering Better Quality E-governance to All Citizens," Government Information Quarterly (in press).

34. Paul T. Jaeger and Kim M. Thompson, "E-government around the World: Lessons, Challenges, and New Directions," Government Information Quarterly 20, no. 4 (2003): 389-94; Paul T. Jaeger and Kim M. Thompson, "Social Information Behavior 
and the Democratic Process: Information Poverty, Normative Behavior, and Electronic Government in the United States," Library \& Information Science Research 26, no. 1 (2004): 94-107.

35. Paul T. Jaeger, "Deliberative Democracy and the Conceptual Foundations of Electronic Government," Government Information Quarterly 22, no. 4 (2005): 702-19; Paul T. Jaeger, "Information Policy, Information Access, and Democratic Participation: The National and International Implications of the Bush Administration's Information Politics," Government Information Quarterly (in press).

36. Bertot et al., "Public Access Computing and Internet Access in Public Libraries"; Bertot et al., "Drafted."

37. Aimee C. Quinn and Laxmi Ramasubramanian, "Information Technologies and Civic Engagement: Perspectives from Librarianship and Planning," Government Information Quarterly (in press).

38. Bertot et al., Public Libraries and the Internet 2006; Paul T. Jaeger et al., "The 2004 and 2005 Gulf Coast Hurricanes: Evolving Roles and Lessons Learned for Public Libraries in Disaster Preparedness and Community Services," Public Library Quarterly (in press).

39. Bertot et al., "Drafted."

40. Jaeger et al., "The 2004 and 2005 Gulf Coast Hurricanes."

41. Ibid.

42. Ibid.

43. Michael Arnone, "Storm Watch 2006: Ready or Not," Federal Computer Week, June 5, 2006, www.fcw.com/print/12_20/ news/94711-1.html (accessed May 19, 2007).

44. Jaeger et al., "The 2004 and 2005 Gulf Coast Hurricanes."

45. Bertot et al., "Public Access Computing and Internet Access in Public Libraries."

46. Jaeger et al., "The 2004 and 2005 Gulf Coast Hurricanes."

47. Ibid.

48. Ibid.

49. Bertot et al., "Public Access Computing and Internet Access in Public Libraries."

50. Paul T. Jaeger et al., "911.gov: Harnessing E-government, Mobile Communication Technologies, and Social Networks to Promote Community Participation in Emergency Response," Telecommunications Policy (in press); Ben Shneiderman and Jenny Preece, "911.gov: Community Response Grids," Science 315 (2007): 944.

51. Kim Viborg Andersen and Helle Zinner Henriksen, "E-Government Research: Capabilities, Interaction, Orientation, and Values," Current Issues and Trends in E-Government Research, Donald F. Norris, ed., 269-88 (Hershey, Pa.: Cybertech, 2007).

52. Jeffrey Roy, "E-Government in Canada: Transition or Transformation?" Current Issues and Trends in E-Government Research, Donald F. Norris, ed., 44-67 (Hershey, Pa.: Cybertech, 2007), 51.

53. OECD e-Government Studies, The E-government Imperative (Danvers, Mass.: Organization for Economic Co-Operation and Development, 2005), 45.

54. Bruce Barber, Strong Democracy (Berkeley, Calif.: Univ. of California Pr., 1984).

55. Bertot et al., Public Libraries and the Internet 2006.

56. Charles R. McClure et al., E-government and Public Libraries: Current Status, Meeting Report, Findings, and Next Steps
(Tallahassee, Fla.: Information Use Management and Policy Institute, 2007), www.ii.fsu.edu/announcements/e-gov2006/ egov_report.pdf (accessed May 19, 2007).

57. Paul T. Jaeger et al., "Public Libraries and Internet Access across the United States: A Comparison by State from 2004 to 2006," Information Technology and Libraries 26, no. 2 (2007): 4-14.

58. Jaeger et al., "The 2004 and 2005 Gulf Coast Hurricanes."

59. Bertot et al., "Drafted."

60. Jaeger et al., "Public Libraries and Internet Access across the United States."

61. Beth Simone Noveck, "Designing Deliberative Democracy in Cyberspace: The Role of the Cyber-lawyer," Boston University Journal of Science and Technology 9 (2003): 1-91.

62. S. H. Holden and L. I. Millett, "Authentication, Privacy, and the Federal E-government," Information Society 21 (2005): 367.

63. E-government Act of 2002, P.L. 107-347; Jaeger, "Deliberative Democracy and the Conceptual Foundations of Electronic Government"; E-government Strategy: Implementing the President's Management Agenda for E-government (Washington, D.C.: EGov, 2003), www.whitehouse.gov/omb/egov/2003egov_strat.pdf (accessed May 19, 2007).

64. Anderson Office of Government Services, A Usability Analysis of Selected Federal Government Web Sites (Anderson Office of Government Services: Washington, D.C., 2002), 1.

65. Christopher G. Reddick, "Citizen Interaction with E-government: From the Streets to Servers?," Government Information Quarterly 22, no. 1 (2005): 338-57.

66. John B. Horrigan, Politics Online (Washington, D.C., Pew Internet \& American Life Project, 2006); John B. Horrigan and Lee Rainie, Counting on the Internet (Washington, D.C., Pew Internet \& American Life Project, 2002).

67. Stephen Barr, "Public Less Satisfied with Government Websites," Washington Post, Mar. 21, 2007, www.washingtonpost. com/wp-dyn/content/article/2007/03/20/AR2007032001338. html (accessed May 19, 2007).

68. Lotte E. Feinberg, "FOIA, Federal Information Policy, and Information Availability in a Post-9/11 World," Government Information Quarterly 21 (2004): 439-60; Elaine L. Halchin, "Electronic Government: Government Capability or Terrorist Resource," Government Information Quarterly 21 (2004): 406-19: Harold C. Relyea and Elaine L. Halchin, "Homeland Security and Information Management," The Bowker Annual: Library and Trade Almanac 2003, D. Bogart, ed., 231-50 (Medford, N.J.: Information Today, 2003).

69. Jaeger, "Information Policy, Information Access, and Democratic Participation."

70. John B. Horrigan, How Americans Get in Touch with Government (Washington, D.C., Pew Internet \& American Life Project, 2004).

71. Bertot et al., "Public Access Computing and Internet Access in Public Libraries"; Bertot et al., "Drafted."

72. The description of the University of Maryland's e-government master's program is available at www.clis.umd.edu/ programs/egov.shtml.

73. Jaeger and Burnett, "Information Access and Exchange among Small Worlds in a Democratic Society." 